\title{
The Development of Global Higher Education in a World of Transformation
}

\author{
Evan G. Mense ${ }^{1}$, Pamela A. Lemoine ${ }^{2}$, Christopher J. Garretson ${ }^{3} \&$ Michael D. Richardson ${ }^{3}$ \\ ${ }^{1}$ Southeastern Louisiana University, USA \\ 2 Troy University, USA \\ ${ }^{3}$ Columbus State University, USA \\ Correspondence: Michael D. Richardson, Columbus State University, USA.
}

Received: November 19, 2018

Accepted: December 25, 2018 Online Published: December 28, 2018

doi:10.20849/jed.v2i3.529

URL: https://doi.org/10.20849/jed.v2i3.529

\begin{abstract}
Globalization has forced higher education into a new world, a world of change, instability and ambiguity, shaped by an increasingly integrated world economy, technology, an international knowledge network, and other forces beyond the control of higher education institutions. Futurists predict that the education systems of tomorrow will be drastically different from those of today. They forecast innovative approaches to teaching and learning will proliferate and will be used more effectively because of technology and telecommunications. Traditional universities historically have been producers of knowledge in the form of human capital, research, and scholarship and are now challenged to tap into the expanding need for lifelong learning. The need and desire for higher education are growing, but higher education is challenged to make significant changes driven by globalization and technology.
\end{abstract}

Keywords: higher education, globalization, technology, commodity, knowledge-based economy

\section{Introduction}

Globalization has driven higher education into a world of change, instability and ambiguity (Douglass, King \& Feller, 2009). Globalization, a key reality in the 21 st century, mandated that higher education critically examine the role and mission of each institution in the profound, changing requirements in a global society (Zhu, 2015). Globalization is defined as reality shaped by an increasingly integrated world economy, new information and communications technology, the emergence of an international knowledge network, and other forces beyond the control of higher education institutions (Altbach, 2016; Mishra, 2013).

Technological changes are occurring at such an accelerating rate that the production of knowledge makes management imperative but often inconsistent (Lemoine, Hackett \& Richardson, 2016a). Futurists predict that the education systems of tomorrow will be drastically different from those of today (Kaiser, Maassen, Meek, van Vught, de Weert \& Goedegebuure, 2014). They forecast that new approaches to teaching and learning will proliferate and will be used more effectively because of educational technology and telecommunications (Bernard, Borokhovski, Schmid, Tamim \& Abrami, 2014). However, some warn that expansion of opportunities and programs should also include assessment and evaluation systems to answer questions of quality (Sobe, 2015).

Concepts of quality in higher education vary between countries and regions, and the programs of regional quality reflect these differences (de Wit \& Hunter, 2017). But perceptions of quality are changing, and the growing emphasis on outcomes and standards heralds the possibility of more dramatic techniques for assessing and evaluating technology and education within a global context (Krokhmal \& Simutina, 2018; Lemoine, Jenkins \& Richardson, 2017). Traditional universities historically have been producers of knowledge in the form of human capital, research, and scholarship and are now challenged to tap into the expanding need for lifelong learning (Kemp, 2016). The need and desire for higher education are growing, but the sustainability of higher education in its present form has become a concern (Avdeeva, Kulik, Kosareva, Zhilkina \& Belogurov, 2017) primarily because higher education significantly contributes to social equity and promotes economic security (Hudson, 2016; Malee-Bassett, 2015). 
New university roles are essential for economic growth by the generation and application of new information and knowledge (Bates, 2010; Goodman \& Gee, 2018). Colleges and universities, traditionally, were regarded as places to go, land-based institutions where students meet teachers in a face-to-face setting to become informed (Kauppi \& Errkla, 2011). Students emerge from traditional universities certificated and credentialed, necessary tools for upward social and economic mobility, but at what cost (Lane, Kehr \& Richardson, 2010)? Higher education institutions confront decreased funding during a time of scarce resources yet increased accountability for productivity in the development and articulation of knowledge and services (Chan, Mense, Crain-Dorough, Richardson, \& Lane, 2013; Jongbloed \& Vossensteyn, 2016). However, technology has disrupted the traditional, formal processes of higher education (Bates, 2010; Hogan, 2015). Using emerging technologies as an accelerant, higher education institutions are separating from traditional brick and mortar physical spaces and venturing into a virtual mélange of educational models used in the knowledge economy (Guri-Rosenblit, 2010; Kruss, Mcgrath, Petersem \& Gastrow, 2015; Youngs, 2013).

\section{What Are the Roles of Higher Education?}

Historically, higher education was a requirement for the preparation of professionals and perceived as a necessity (Spring, 2014). Most recently, higher education has become a profitable business framework, an online business model, and a higher education corporate machine, presenting education as a commodity of knowledge-based products for the economic market (Bagley \& Portnoi, 2014; Baumann, 2017). Embedded in all of these concepts and, it could be argued, emerging from them, is the perception that access to knowledge and learning is a universal right, one of the key rights of the global community (Kauppinen, 2012, 2014). In fact, knowledge is increasingly regarded as the solution to individual and collective social and economic problems, i.e., a new global religion (Lane, Lemoine, Tinney \& Richardson, 2014a, 2014b). However, this new "religion" now faces inevitable deliberations and debates regarding knowledge imperialism and the new marginalization for those on the edge (Machin \& Murphy, 2017). Those who are successful in the new global knowledge economy may harvest great wealth and exert an inordinate influence on the world's future (Nicotra \& Patel, 2016). However, those at the edges continue to be marginalized and left behind in the push for economic prosperity (Monteiro \& Sharma, 2014).

\section{What Is Globalization and the Knowledge Economy?}

Globalization creates and encompasses markets and competition between institutions and between nations (Samier, 2015). Globalization rendered the different national systems more similar to each other in form, in mission and organizational language (Kahn, 2015). Globalized competition, performance funding and transparency transform institutions and nations more prepared for the global challenge (Jarvis, 2013; Lane, 2015).

Global higher education is more open than are national systems, with a wide range of opportunities for innovations, alliances and markets (Mok, 2015). To maximize effectiveness in the global environment it is essential for higher education institutions to retain a strong sense of identity and purpose (Stensaker, Lee, Rhoades, Ghosh, Castiello-Gutiérrez, S. Vance, Çalıkoğlu, Kramer, Liu, Marei, \& O’Toole, 2018). Conversely, it is necessary to be open to and engaged with others (Stromquist \& Monkman, 2014). Simultaneously, effectiveness in the global environment means being prepared to change, to modify and adapt quickly and efficiently (Lane, Lemoine, Tinney \& Richardson, 2014b). Governments in many nations are debating and assessing whether competition at home improves competitiveness abroad, and which combination of competition with collaboration will deliver the best results (Pucciarelli \& Kaplan, 2016). Governments typically recognize that effective systems of higher education contribute to the link between knowledge and skills and long-term economic development (Lovett, 2013; Morley, Marginson \& Blackmore, 2014).

Globalization with changes in the world's economy, increasing diversity, and the ubiquitous use of technology creates unprecedented opportunities and challenges for higher education (Anderson, 2015; Slaughter, 2014; Wadhwa, 2016). Spring (2014), suggested colleges and universities are "already in the best position to benefit from, and contribute to, the increasing exchange of knowledge" (p. 93). Since the global knowledge economy requires advanced education, colleges and universities face a move from more formal traditional roles of working for the public good to redefining their institutional mission to include innovation, entrepreneurship, and marketing (Guri-Rosenblit, 2010; Pinheiro \& Stensaker, 2014). The digital economy offers tremendous opportunities for higher education institutions that can adapt (Lane, Lemoine, Tinney, \& Richardson, 2014b). Digital technologies are creating greater access to education, new markets for distribution, and expanded income opportunities for higher education institutions (Bano \& Taylor, 2015; Weller \& Anderson, 2013). 
In today's evolving global educational marketplace students are accustomed to instant access, any time, any place (Jones \& Skinner, 2014). Ubiquitous anytime, anywhere learning is attractive to adult learners who balance both home and career (Barton \& Ryan, 2014). With technological innovations creating cross-broader access to higher education, there are increasing opportunities for higher education institutions to expand revenue sources by selling knowledge (Barrett, 2017c). Accordingly, higher education institutions are positioning themselves in the national and international market as entrepreneurial models (Barnett, 2011; Lane, Lemoine, Tinney \& Richardson, 2014a).

Change is necessary for higher education institutions to remain viable (Khan, 2015; Marshall, 2010: Saarinen \& Valimaa, 2012). Survival for many higher education institutions necessitates adaptation of traditional educational paradigms and generating a new model of global engagement (Kedziora, Klamut, Karri \& Kraslawski, 2017). The physical university is now a combination multi-dimensional education model: physical and online, or online (Tapscott \& Williams, 2010). Consequently, universities are using technology as one of the primary means for initiating and maintaining contact with a diverse and changing student population looking for anywhere, anytime learning (Bates, 2010; Lewis \& Lingard, 2015; Mense, Fulwiler, Richardson \& Lane, 2011; Soares, 2012; Zhao, 2012, 2015).

Globalization and technological changes, while presenting tremendous challenges, bring vast opportunities. Globalization, for example, vastly expands the pool of potential customers for products and services. Niche talents that used to be of only interest to a small fraction of people may not be of much value locally because the total population is small in a given community. In the globalized world, the potential customers could be seven billion people. Even a small fraction of seven billion can be significant. Additionally, talents that may be of little value in a given location can be very valuable in another. Globalization and technology today enable products and services to reach almost any corner of the world. (Zhoa, 2012, p. 44-45)

Thus, in the push to be globally competitive, every country, large or small, is tackling some means and methods for reforming higher education to make it more of a service to the country (Altbach, 2014; Anderson, 2015; Barrett, 2017a).

\section{How Does Globalization Impact Higher Education?}

Researchers predict that 80 percent of new jobs created in the global knowledge economy will require advanced education (Kauppinen, 2015). However, colleges and universities are deliberately altering their traditional roles and redefining their institutional mission to include innovation and entrepreneurship (Balán, 2015). Universities are now battling borderless, global competitors moving into the business of higher education (Ball, 2010; Teichler, 2017). To stay viable in the knowledge economy, higher education institutions need to become business-like entrepreneurs by marketing themselves (Judson \& Taylor, 2014), building collaborative alliances (Tadaki \& Tremewan, 2013), and preparing for newer, emerging disruptive technologies and an expanded student base which is more diverse and specialized (Bickerstaff \& Cormier, 2015; Cheng, 2016).

Higher education, the right to be educated, to acquire knowledge to overcome poverty, and to increase social position has been called the great equalizer in society (Conner \& Rabovsky, 2011); however, traditional higher education was not equally accessible by all (Feenstra \& Hanson, 2014). Is higher education still the great equalizer, the opportunity to overcome poverty, increase social class, and to become a functional societal member or has that message been subverted (Tannock, 2013)? Is higher education a platform to address racial inequality and the rights of the marginalized to be educated? In 1948, the United Nations Universal Declaration of Human Rights established education as entitlement for all children; however, changing politics, demographics, and economics have changed educational paradigms and subverted the value attributed to higher education (McClure, 2016; Zajda, 2015).

Globalization forced higher education institutions to critically examine their participation in the international environment and to assess their involvement in a changing world (Allais, 2017; Marginson, 2006). Technology created a vast new expanse of potential markets for higher education in a global market place (Moreira, 2016). The potential for pluralization of power in global higher education; the mobility of people, information and the expanded influence of technology, globalization and higher education all play a vital role in the knowledge economy (de Wit, 2015; Ornstein \& Eng, 2015; Siddiqui, 2014).

Higher education is increasingly viewed as a major stimulus for both economic and social development (Barrett, 2017b). However, in most countries government revenues are not keeping pace with rapidly rising costs of higher education, hence the dramatic increase in student tuition and fees. The expansion of student numbers presents a major challenge to provide access to quality higher education (Ball, 2012). In financial terms, this has become an unsustainable model, placing pressure on systems to fundamentally restructure the 'social contract' 
between higher education and society at large where parents and/or students are increasingly responsible for tuition and other fees (Demange, Fenge \& Uebelmesser, 2014). What is the tipping point; the point at which society perceives that the cost of higher education outweighs the potential benefits?

Government is ultimately responsible for the development of higher education in every country, but the trends are obvious: those countries with the most vibrant higher education systems are those that are most productive (Hazelkorn, 2015). Both the social and economic futures of countries depend heavily on the educational attainment of their population and the quality of their higher education institutions (Sharma, 2014). However, citizens and governments are beginning to examine their return on investment in higher education (McGowan \& Sckendel, 2015). At what point do governments decide that the cost of higher education is greater than the cost to maintain higher education programs and services? Will they increasingly turn to for-profit institutions to provide the same services and programs at no cost except to the parents and/or students? Will they abdicate their responsibility for preparing citizens for the global knowledge economy?

\section{What Are the Interpretations of Globalization in Higher Education?}

In this era of VUCA (volatility, uncertainty, complexity, ambiguity) a term coined for the military world also describes today's higher education environment. VUCA describes the chaotic, turbulent, and rapidly changing education atmosphere, which some have suggested as the new normal for higher education and indeed for society (Lemoine, Hackett, \& Richardson, 2016b). Globalization has also created many VUCA factors because it entails the formation of world-wide markets operating in real time in common financial systems with unprecedented levels of foreign direct investment and cross-border mobility of production and people (Bosire \& Amimo, 2017). Conversely, globalization is founded on the first world-wide systems of communications, information, knowledge and culture, tending towards a single world community (Carnoy, 2014).

The continuously extending networks based on travel, mobile phones, broad-band Internet and other information and communications technologies (ICTs), are creating new techniques for human association, of unprecedented scale and flexibility while spanning cities and nations with varied cultures and levels of economic development (Demange, Fenge \& Uebelmesser, 2014; Deschamps \& Lee, 2015). The networks enable the complex data transfers essential to knowledge-intensive production (Feigenbaum \& Iqani, 2015). The processes of communication and information, where the economic and cultural aspects are drawn together, constitute what is new about globalization; and inclusion/exclusion. ICT networks and knowledge have created key dividing lines in shaping relations of power and inequality (Ferreira, Haddad \& Faria, 2014; Knight, 2015).

\section{Is Higher Education a Public Good?}

The movement or trade in goods and services, including educational services, across international borders is viewed as the crucial economic outcome of globalization (Torres, 2015). Important international decision makers, policy-makers and politicians consider higher education to be a tradable commodity as well as a social service and often a privilege (Qureshi \& Nair, 2015).

Historically higher education was regarded as a public good producing enormous benefit not only to individuals but also the entire society (Kauppinen, 2014). By most interpretations higher education constitutes a public good in itself that produces public goods, benefiting simultaneously citizens and society (Carnoy, Froumin, Loyalka, \&Tila, 2014). Higher education, as a public good should spread benefits to the citizenry. In addition, higher education institutions have multiple objectives, not just economic. They produce multiple, varied types of outputs, some tangible and many not. Because of these special features, public goods like higher education cannot be provided by countries in a manner that always satisfies social demand or on the timelines desired (Shakar \& Plater, 2016).

The public good nature of higher education is well understood in reference to the traditional functions of higher education and the social benefits provided (Lodge \& Bonsaquet, 2014). However, higher education is facing two severe impediments; growth and sustainability (Walker, 2015). First, governments around the world have steadily minimized their support for public higher education, and expenses have increased constantly over the last decade (Feigebaum \& Iqani, 2015). Second, governments are increasing pressure on universities to demonstrate the value of their degrees in short-term, quantitative and market-related measures (Blanco-Ramirez $\&$ Berger, 2014).

Most universities are now forced to adopt a unique form of corporate restructuring creating a corrosive influence of commoditizing education related to the standardization of degree production in institutions asked to make a profit from large numbers of student-consumers (Altbach, 2015; Ball, 2012). In a time when ecological, social, cultural and economic challenges require innovative solutions and new concepts, higher education must deliver 
both creativity for sustainability and resilience for accountability (Balán, 2015). This dilemma forces universities to pursue both excellence and equity in a climate of accountability and competition, an almost impossible dilemma (Koyama \& Kania, 2014; Teichler, 2017).

Some researchers suggest the policy reforms of the last several decades, which have introduced greater "privatization" and market competition into higher education systems, have also lessened the "public goods" provided by higher education institutions and are compromising academic integrity within universities (Brown, 2015). Although global higher education has a potential to increase access to higher education, deep concerns have been raised about the equity of access (King, 2013).

As learning becomes increasingly borderless, higher education policy is likely to rank increasingly high on national agendas (Temple, 2011; Youngs, 2013). Developing countries view increasing higher education participation as crucial to their transition to developed country standing and to providing opportunities for their citizens in the knowledge economy (Hall, 2013). The argument that higher education is a major driver of economic competitiveness in an increasingly global knowledge economy is now widely accepted, but does it contribute to the public good (Li \& Lowe, 2016; Tekleselassie, Roberts \& Richardson, 2014)?

\section{What Is the Influence of Technology in Higher Education?}

Technology has created a new higher education, particularly in the international marketplace (Cantwell \& Kauppinen, 2014; Van Nyhuis, 2018). Understanding new information and communication technologies are essential for administrators of higher education systems in both a local and global perspective (Chapleo \& O'Sulliven, 2017). Higher education institutions are more important than ever in building a wide range of relationships and a continuous flow of resources (Zhu, 2015). Technology is transforming higher education by providing a global focus, thereby intensifying the global interconnectedness (Audretsch, Lehmann \& Wright, 2014). Technology has now become central to the global changes: reshaping social, economic and cultural life as well as higher education (Richardson, Jenkins \& Lemoine, 2017). Technology has not created international universities, but all are impacted by the conceptual and realistic impact of globalism, both in terms of education (instruction) (Audretsch, 2014) and resources (students) (Devi, Bimol \& Saikia, 2014).

The first world-wide systems of communications, information, knowledge and culture binds the world together and creates a global interrelated state (Cheng, Cheung \& Ng, 2016). During the past decade, technical innovations have altered the skills and knowledge needed to succeed in the workplace and society (de Wit, 2017). Preparing technically educated and skilled individuals is of great economic importance to countries and requires significant attention from both educators and employers (Woodard, Shepherd, Crain-Dorough \& Richardson, 2011). Higher education institutions around the world provide students with the knowledge and skills necessary to function in society both personally and at work (Miller, 2010). Now that society has assumed a global focus, supported by technology, higher education institutions are asked to offer the highest quality education, especially technology literacy, to a widely diverse audience at a cost that can be supported by society (Lemoine \& Richardson, 2019; Li \& Zhao, 2015).

\section{What Are the Economic and Financial Considerations of Globalization for Higher Education?}

Economic and technological changes are occurring at an accelerating rate in the knowledge society, making life-long learning for everyone a necessity for success in the work place (Peters, 2010). This is particularly the case in the transition period from industrial production to a knowledge-based economy. Today's college graduates will change careers multiple times, each change requiring access to lifelong learning with additional education being required at each career change (Bickerstaff \& Cormier, 2015). Therefore, access to higher education is a necessity for job mobility and economic success (Orstein \& Eng, 2015; Wangenge-Ouma, 2014).

Most of the elements of society, particularly higher education, are struggling with globalization across cultures and around the world (Morley, Marginson \& Blackmore, 2014). The globalization of higher education places a new emphasis on both the content and process of education coupled with global and economic ramifications for delivery (Yeoh, Foong \& Ho, 2014). Consequently, higher education is increasingly viewed as a major engine of economic development throughout the world (Lane, Kehr \& Richardson, 2010).

Globally, universities are being forced to reconsider their missions and goals (Taylor \& Morphew, 2015). Society no longer grants privilege and financial commitment to higher education because tax dollars are scarce (Elbasir \& SiddiquI, 2018; Molesworth, Scullion \& Nixon, 2011). Many perceive that those receiving the most from higher education institutions should pay for the privilege, thereby dramatically increasing tuition and fees (Allen \& Withey, 2017; Amy, 2016). Many perceive higher education to be very costly, yet it is also widely seen as highly beneficial to a country's economy and cultural vibrancy (Bergh \& Nilsson, 2010). For many in 
underserved regions of the world, higher education has become necessary for social mobility and economic success although cost remains an enormous barrier (Castro, 2015; Dewi, 2018; Hackett, Lemoine \& Richardson, 2016). As a result, higher education has also experienced a new demand for financial accountability (Guerrero, Cunningham \& Urbano, 2015). With increasing demands regarding healthcare, public safety, and quality of life issues taking priority, many, particularly policy makers and politicians perceive that those benefiting from higher education should pay the cost (Bolli, Olivares, Bonaccorsi, Daraio, Aracil, \& Lepori, 2016; Heyneman \& Lee, 2013; Krucken, 2014).

In addition, demographic changes also pose direct, long-term challenges to universities (Seeber, Cattaneo, Huisman \& Paleari, 2016). An aging population shapes spending priorities for many in the global market. Many countries are being forced to compete for talent with each other, striving not only to keep their own students at home, but also to recruit and retain talented students and workers from other countries (Beech, 2011; Horta, 2010; Teichler, 2017). In addition, an ever-expanding diverse society, including growing minority populations and high rates of immigration (Charles, 2018; Peercy \& Svenson, 2016), assures that colleges and universities will need additional resources to meet the needs of these diverse students (Brown, Bull \& Pendlebury, 2013; Mohsin \& Zaman, 2014; Shin \& Kehm, 2013).

Colleges and universities are important incubators for finance, talent and innovation (Guerrero, Cunningham \& Urbano, 2015; Proenza, 2010). They attract top students, resourceful faculty, prestigious research grants, business and jobs and are a huge revenue generator when used effectively and efficiently (Goodman \& Gee, 2018; Mok, 2015). They generate revenue and resources and are uniquely positioned to provide leadership for future innovation, development and change (Lane, Kehr \& Richardson, 2009).

Economic considerations related to international competitiveness have become a significant driving strength behind the globalization of teaching and learning (Stafford \& Taylor, 2016). Along with the movement of goods and general services, the movement of educational services and products has improved significantly in the last decade (Dubina, Carayannis \& Campbell, 2012). Higher education is increasingly seen not only as an export commodity, but also as a key national brand for a nation's knowledge proficiency (Bano \& Taylor, 2015; Greenwood, Raynard, Kodeih, Micelotta, \& Lounsbury, 2011). Knowledge institutions, whether private or public, are regarded as significant stakeholders in a country's global and local competitiveness (Foss \& Gibson, 2015; Haapalorpi \& Saairen 2014).

\section{Concluding Thoughts}

Historically, education was viewed as a basic human need, and by some as a right, and a key factor in social and economic development. Investment in education was perceived to raise the well-being of individuals while elevating their 'human capital' and economic capacity. Education was also viewed as a means of reducing inequality and a venue for social development. The capacities for countries to adopt, disseminate, and maximize rapid technological and educational improvements were reliant on adequate systems of education. The marketing and selling of education at the international level has had both positive and negative effects on the global knowledge economy because stakeholders are increasingly asking whether students are learning and whether institutions are providing a quality of service that justifies their cost.

Governments across the world have steadily minimized their support for public higher education, and costs associated with gaining a degree have increased constantly over the last decade. Most universities are forced to adopt a restructuring model for commoditizing education to make a profit from large numbers of students. The road ahead for higher education is filled with challenges, risks and uncertainties that begin with education being valued as more than a simple commodity: education becomes a public good. Higher education is increasingly viewed as a major instrument of economic development. In order to hold universities accountable despite limited governmental budgets, many nations have adopted performance-based university research funding strategies for targeted programs. Citizens and politicians in many countries are asking more frequently what tangible benefits the society is receiving for the tax revenues being spent on higher education.

Higher education is implicated in all these economic and global changes. Higher education is a key element in the formation of an international environment that is swept up in global marketization. Consequently, is higher education a commodity to be bought and sold or is it a service in the creation of economic globalism? Regardless, higher education is essential to the creation, exchange and implementation of knowledge in a global marketplace with many unintended consequences, like accountability. Globalization creates an atmosphere in higher education where knowledge and information are highly prized for their capability of increasing integration. Thus, under the influence of globalization, changes in higher education offer significant opportunities for most universities to succeed in the market of higher education services. 


\section{References}

Allais, S. (2017). Towards measuring the economic value of higher education: Lessons from South Africa. Comparative Education, 52(1), 147-163. https://doi.org/10.1080/03050068.2017.1254985

Allen, P., \& Withey, P. (2017). The student customer phenomenon. Journal of Higher Education Theory and Practice, 17(3), 45.

Altbach, P. (2015). Knowledge and education as international commodities. International Higher Education, (28), 2-5. https://doi.org/10.6017/ihe.2002.28.6657

Altbach, P. G. (2014). India's higher education challenges. Asia Pacific Education Review, 15(4), 503-510. https://doi.org/10.1007/s12564-014-9335-8

Altbach, P. G. (2016). Global perspectives on higher education. Baltimore, MD: JHU Press.

Amy, L. (2016). Dramatic declines in higher education appropriations: State conditions for budget punctuations. Research in Higher Education, 58(4), 395-429

Anderson, T. (2015). Seeking internationalization: The state of Canadian higher education. Canadian Journal of Higher Education, 45(4), 166-187.

Audretsch, D. B. (2014). From the entrepreneurial university to the university for the entrepreneurial society. The Journal of Technology Transfer, 39(3), 313-321. https://doi.org/10.1007/s10961-012-9288-1

Audretsch, D. B., Lehmann, E. E., \& Wright, M. (2014). Technology transfer in a global economy. The Journal of Technology Transfer, 39(3), 301-312. https://doi.org/10.1007/s10961-012-9283-6

Avdeeva, T. I., Kulik, A. D., Kosareva, L. A., Zhilkina, T. A., \& Belogurov, A. Y. (2017). Problems and prospects of higher education system development in modern society. European Research Studies Journal, 20(4B), $112-124$.

Bagley, S. S., \& Portnoi, L. M. (2014). Setting the stage: Global competition in higher education. New Directions for Higher Education, 2014(168), 5-11. https://doi.org/10.1002/he.20109

Balán, J. (2015). The crisis of the public mission in higher education. International Higher Education, (80), 4-5. https://doi.org/10.6017/ihe.2015.80.6130

Ball, S. J. (2010). Privatising education, privatizing education policy, privatizing educational research: Network governance and the "competition state." Journal of Education Policy 24(1), 83-99. https://doi.org/10.1080/02680930802419474

Ball, S. J. (2012). The reluctant state and the beginning of the end of state education, Journal of Educational Administration and History, 44(2), 89-103. https://doi.org/10.1080/00220620.2012.658764

Bano, S., \& Taylor, J. (2015). Universities and the knowledge-based economy: Perceptions from a developing

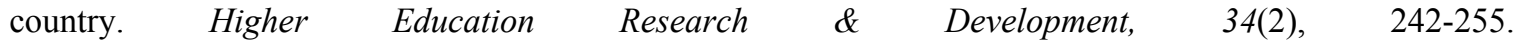
https://doi.org/10.1080/07294360.2014.956696

Barnett, R. (2011). The marketised university: Defending the indefensible. In M. Molesworth, R. Scullion, \& E. Nixon (Eds.), The marketisation of higher education and the student as consumer (pp. 39-51). London: Routledge.

Barrett, B. (2017a). Background on higher education policy in Europe. In B. Barrett (Ed.), Globalization and change in higher education (pp. 1-9). London: Palgrave Macmillan. https://doi.org/10.1007/978-3-319-52368-2_1

Barrett, B. (2017b). Historical institutionalism and change in higher education. In B. Barrett (Ed.), Globalization and change in higher education (pp. 35-55). London: Palgrave Macmillan. https://doi.org/10.1007/978-3-319-52368-2_3

Barrett, B. (2017c). The dual roles of higher education institutions in the knowledge economy. In B. Barrett (Ed.), Globalization and change in higher education (pp. 57-73). London: Palgrave Macmillan. https://doi.org/10.1007/978-3-319-52368-2_4

Barton, G., \& Ryan, M. (2014). Multimodal approaches to reflective teaching and assessment in higher education. Higher Education Research \& Development, 33(3), 409-424. https://doi.org/10.1080/07294360.2013.841650 
Bates, T. (2010). New challenges for universities: Why they must change. In U. D. Ehlers, \& D. Schneckenberg (Eds.), Changing cultures in higher education (pp. 15-25). Berlin: Springer. https://doi.org/10.1007/978-3-642-03582-1_2

Baumann, C. (2017). Managing processes of globalization. Comparativ, 27(3-4), 186-202.

Beech, J. (2011). Global panaceas, local realities: International agencies and the future of education. Frankfurt, Germany: Peter Lang.

Bergh, A., \& Nilsson, T. (2010). Do liberalization and globalization increase income inequality? European Journal of Political Economy, 26(4), 488-505. https://doi.org/10.1016/j.ejpoleco.2010.03.002

Bernard, R. M., Borokhovski, E., Schmid, R. F., Tamim, R. M., \& Abrami, P. C. (2014). A meta-analysis of blended learning and technology use in higher education: From the general to the applied. Journal of Computing in Higher Education, 26(1), 87-122. https://doi.org/10.1007/s12528-013-9077-3

Bickerstaff, S., \& Cormier, M. S. (2015). Examining faculty questions to facilitate instructional improvement in $\begin{array}{lllll}\text { higher education. Studies in Educational Evaluation, } & 46, & \text { 74-80. }\end{array}$ https://doi.org/10.1016/j.stueduc.2014.11.004

Blanco-Ramírez, G., \& B. Berger, J. (2014). Rankings, accreditation, and the international quest for quality: Organizing an approach to value in higher education. Quality Assurance in Education, 22(1), 88-104. https://doi.org/10.1108/QAE-07-2013-0031

Bolli, T., Olivares, M., Bonaccorsi, A., Daraio, C., Aracil, A.G., \& Lepori, B. (2016). The differential effects of competitive funding on the production frontier and the efficiency of universities. Economics of Education Review, 52, 91-104. https://doi.org/10.1016/j.econedurev.2016.01.007

Bosire, J., \& Amimo, C. (2017). Emerging issues and future prospects in the management of transnational education. International Journal of Higher Education, 6(5), 143. https://doi.org/10.5430/ijhe.v6n5p143

Brown, G. A., Bull, J., \& Pendlebury, M. (2013). Assessing student learning in higher education. New York, NY: Routledge.

Brown, R. (2015). The marketisation of higher education: Issues and ironies. Liverpool, England: Liverpool Hope University.

Cantwell, B., \& Kauppinen, I. (Eds.) (2014). Academic capitalism in the age of globalization. Baltimore, MD: Johns Hopkins University Press.

Carnoy, M. (2014). Globalization, educational change, and the national state. Globalization and education. Integration and contestation across cultures (pp. 21-38). Lanham, MD: Rowman \& Littlefield.

Carnoy, M., Froumin, I., Loyalka, P. K., \& Tila, J. B. (2014). The concept of public goods, the state, and higher education finance: A view from the BRICs. Higher Education, 68(3), 359-378. https://doi.org/10.1007/s10734-014-9717-1

Castro, M. H. (2015). Higher education policies in Brazil: A case of failure in market regulation. In S. Schwartzman, R. Pinheiro, \& P. Pillay (Eds.), Higher education in the BRICS countries: Investigating the pact between higher education and society (pp. 271-290). Drodrecht, The Netherlands: Springer.

Chan, T. C., Mense, E. G., Crain-Dorough, M., Richardson, M. D., \& Lane, K. E. (2013). Observations through a keyhole: The changing dimension of global higher education. In S. Mukerji, \& P. Tripathi (Eds.), Handbook of research on transnational higher education management (pp. 59-78). Hershey, PA. IGI.

Chapleo, C., \& O'Sullivan, H. (2017). Contemporary thought in higher education marketing. Journal of Marketing for Higher Education, 27(2), 159-161. https://doi.org/10.1080/08841241.2017.1406255

Charles, A. C. (2018). Access to higher education: Understanding global inequalities. The Canadian Journal of Higher Education, 48(1), 154.

Cheng, Y. C. (2016). Paradigm shift in higher education: Learning, internationalisation and development. In Globalisation and higher education reforms (pp. 115-132). New York, NY: Springer. https://doi.org/10.1007/978-3-319-28191-9_8

Cheng, Y. C., Cheung, A. C. K., \& Ng, S. W. (2016). Internationalization of higher education. Singapore: Springer. https://doi.org/10.1007/978-981-287-667-6 
Conner, T. W., \& Rabovsky, T.M. (2011). Accountability, affordability, access: A review of the recent trends in higher education policy research. Policy Studies Journal, 39(1), 93-112. https://doi.org/10.1111/j.1541-0072.2010.00389_7.x

de Wit, H. (2015). Is the international university the future for higher education? International Higher Education, (80), 7.

de Wit, H. (2017). Global: Internationalization of higher education: Nine misconceptions. In Understanding higher education internationalization (pp. 9-12). Rotterdam, Netherlands: Sense Publishers. https://doi.org/10.1007/978-94-6351-161-2_2

de Wit, H., \& Hunter, F. (2017). Europe: The future of internationalization of higher education in Europe. In Understanding higher education internationalization (pp. 25-28). Rotterdam, Netherlands: Sense Publishers. https://doi.org/10.1007/978-94-6351-161-2_6

Demange, G., Fenge, R., \& Uebelmesser, S. (2014). Financing higher education in a mobile world. Journal of Public Economic Theory, 16(3), 343-371. https://doi.org/10.1111/jpet.12064

Deschamps, E., \& Lee, J. J. (2015). Internationalization as mergers and acquisitions: Senior international officers' entrepreneurial strategies and activities in public universities. Journal of Studies in International Education, 19(2), 122-139. https://doi.org/10.1177/1028315314538284

Devi, L. P., Bimol, S., \& Saikia, M. (2014). Information and communication technology influence in education system. International Journal of Information Technology \& Computer Sciences Perspectives, 3(4), 1265.

Dewi, A. U. (2018). Towards knowledge economy: A comparative study of Indonesian and South Korean internationalization of higher education. KnE Social Sciences, 3(10), 63-83. https://doi.org/10.18502/kss.v3i10.2905

Douglass, J. A., King, C. J., \& Feller, I. (2009). Globalization's muse: Universities and higher education systems in a changing world. Berkeley, CA: Berkeley Public Policy Press.

Dubina, I. N., Carayannis, E. G., \& Campbell, D. F. J. (2012). Creativity economy and a crisis of the economy? Coevolution of knowledge, innovation, and creativity, and of the knowledge economy and knowledge society. Journal of the Knowledge Economy, 3(1), 1-24. https://doi.org/10.1007/s13132-011-0042-y

Elbasir, A., \& SiddiquI, K. (2018). Higher education, funding, polices and politics: A critical review. Journal of Social and Administrative Sciences, 5(2), 152-167.

Feenstra, R. C., \& Hanson, G. H. (2014). Globalization, outsourcing and wage inequality. The American Economic Review, 3(2), 86(2).

Feigenbaum, A., \& Iqani, M. (2015). Quality after the cuts? Higher education practitioners' accounts of systemic challenges to teaching quality in times of 'austerity'. Journal of Further and Higher Education, 39(1), 46-66. https://doi.org/10.1080/0309877X.2013.778961

Ferreira, N. S., Haddad, M. E., \& Faria, A. A. (2014). Educational technology and educational management in the higher education: New ways of forming professionals. Open Journal of Social Sciences, 2(02), 7-11. https://doi.org/10.4236/jss.2014.22002

Foss, L., \& Gibson, D. V. (Eds.) (2015). The entrepreneurial university: Context and institutional change. New York, NY: Routledge. https://doi.org/10.4324/9781315737065

Goodman, A. E., \& Gee, E. G. (2018). Leading internationalization: A handbook for international education leaders. Herndon, VA: Stylus Publishing, LLC.

Greenwood, R., Raynard, M., Kodeih, F., Micelotta, E. R., \& Lounsbury, M. (2011). Institutional complexity and organizational responses. The Academy of Management Annals, 5(1), 317-371. https://doi.org/10.5465/19416520.2011.590299

Guerrero, M., Cunningham, J. A., \& Urbano, D. (2015). Economic impact of entrepreneurial universities' activities: An exploratory study of the United Kingdom. Research Policy, 44(3), 748-764. https://doi.org/10.1016/j.respol.2014.10.008

Guri-Rosenblit, S. (2010). Digital technologies in higher education: Sweeping expectations and actual effects. New York, NY: Nova Science

Haapakorpi, A., \& Saarinen, T. (2014). Transnational turn and national models of higher education-The case of Finland. Nordic Studies in Education, 34(3), 187-200. 
Hackett, P. T., Lemoine, P. A., \& Richardson, M. D. (2016). Impact of technology ambiguity on leadership in global higher education. In V. C. X. Wang (Ed.), Encyclopedia of strategic leadership and management. (pp. 270-281). Hershey, PA: IGI.

Hall, R. (2013). Educational technology and the enclosure of academic labour inside public higher education. Journal for Critical Education Policy Studies, 11(3), 52-82.

Hazelkorn, E. (2015). Rankings and the reshaping of higher education: The battle for world-class excellence. London, England: Palgrave Macmillan. https://doi.org/10.1057/9781137446671

Heyneman, S. P., \& Lee, J. (2013). World-class universities: The sector requirements. In J. C. Shin \& B. M. Kehm (Eds.), Institutionalization of world-class universities in global competition (pp. 45-54). New York, NY: Springer. https://doi.org/10.1007/978-94-007-4975-7_4

Hogan, J. (2015). Reshaping the university: The rise of the regulated market in higher education. Perspectives: Policy and Practice in Higher Education, 19(1), 33-34. https://doi.org/10.1080/13603108.2014.963728

Horta, H. (2010). The role of the state in the internationalization of universities in catching-up countries: An analysis of the Portuguese higher education system. Higher Education Policy, 23(1), 63-81. https://doi.org/10.1057/hep.2009.20

Hudson, R. (2016). Dominated by economics? Evidence of changing drivers of internationalization and its funding within higher education institutions in Europe. Higher Education Policy, 29(1), 1-19. https://doi.org/10.1057/hep.2015.4

Jarvis, P. (2013). Universities and corporate universities: The higher learning industry in global society. New York, NY: Routledge. https://doi.org/10.4324/9781315042442

Jones, P., \& Skinner, H. (2014). E-learning globalization: The impact of e-learning-what difference has it made? Education+Training, 56(2-3), 1-4. https://doi.org/10.1108/ET-11-2013-0128

Jongbloed, B., \& Vossensteyn, H. (2016). University funding and student funding: International comparisons. Oxford Review of Economic Policy, 32(4), 576-595. https://doi.org/10.1093/oxrep/grw029

Judson, K. M., \& Taylor, S. A. (2014). Moving from marketization to marketing of higher education: The co-creation of value in higher education. Higher Education Studies, 4(1), 51-67. https://doi.org/10.5539/hes.v4n1p51

Kaiser, F., Maassen, P., Meek, L., van Vught, F., de Weert, E., \& Goedegebuure, L. (Eds.) (2014). Higher education policy: An international comparative perspective. Amsterdam, The Netherlands: Elsevier.

Kauppi, N., \& Errkla, T. (2011). The struggle over global higher education: Actors, institutions, and practices. International Political Sociology, 5(3), 314-326. https://doi.org/10.1111/j.1749-5687.2011.00136.x

Kauppinen, I. (2012). Towards transnational academic capitalism. Higher Education, 64(4), 543-556. https://doi.org/10.1007/s10734-012-9511-x

Kauppinen, I. (2014). Different meanings of 'knowledge as commodity' in the context of higher education. Critical Sociology 40(3), 393-409. https://doi.org/10.1177/0896920512471218

Kauppinen, I. (2015). Towards a theory of transnational academic capitalism. British Journal of Sociology of Education, 36(2), 336-53. https://doi.org/10.1080/01425692.2013.823833

Kedziora, D., Klamut, E., Karri, T., \& Kraslawski, A. (2017). Higher education offshoring as an innovative response to global learning challenges. International Journal of Management, Knowledge and Learning, 6(2), 239-260.

Kemp, N. (2016). The international education market: Some emerging trends. International Higher Education, (85), 13-15. https://doi.org/10.6017/ihe.2016.85.9238

Khan, A. U. (2015). What globalization means for the education sector: How do we cater to emerging needs? Emerging Economy Studies, 1(1), 96-107. https://doi.org/10.1177/2394901514562303

King, R. (Ed.). (2013). The globalization of higher education. Cheltenham, England: Edward Elgar Publishing Ltd.

Knight, J. (2015). International universities: Misunderstandings and emerging models. Journal of Studies in International Education, 19(2), 107-121. https://doi.org/10.1177/1028315315572899 
Koyama, J., \& Kania, B. (2014). When transparency obscures: The political spectacle of accountability. Journal for Critical Education Policy Studies, 12(1), 143-169.

Krokhmal, L. A., \& Simutina, N. L. (2018). Integration in higher education institutions in the global educational system. European Research Studies Journal, 21(2), 586-600.

Krücken, G. (2014). Higher education reforms and unintended consequences: A research agenda. Studies in Higher Education, 39(8), 1439-1450. https://doi.org/10.1080/03075079.2014.949539

Kruss, G., McGrath, S., Petersen, I. H., \& Gastrow, M. (2015). Higher education and economic development: The importance of building technological capabilities. International Journal of Educational Development, 43, 22-31. https://doi.org/10.1016/j.ijedudev.2015.04.011

Lane, J. E. (2015). Higher education internationalization: Why governments care. In E. Ullberg (Ed.), New perspectives on internationalization and competitiveness (pp. 17-30). Dordrecht, Netherlands: Springer. https://doi.org/10.1007/978-3-319-11979-3_3

Lane, K. E., Kehr, G. A., \& Richardson, M. D. (2010). The paradox of productivity measurement in higher education. Academe: Journal of Leadership and Management in Higher Education, 1(3), 23-39.

Lane, K. E., Lemoine, P. A., Tinney, T. M., \& Richardson, M. D. (2014a). Modify and adapt: Global higher education in a changing economy. In M. Khosrow-Pour (Ed.), Economics: Concepts, methodologies, tools, and applications (pp. 1650-1663). Hershey, PA: IGI.

Lane, K. E., Lemoine, P. A., Tinney, T. M., \& Richardson, M. D. (2014b). Modify and adapt: Global higher education in a changing economy. International Journal of Innovation in the Digital Economy (IJIDE), 5(2), 24-36. https://doi.org/10.4018/ijide.2014040103

Lemoine, P. A., \& Richardson, M. D. (2019). Creative disruption in higher education: Society, technology, and globalization. In Educational and social dimensions of digital transformation in organizations (pp. 275-293). Hershey, PA: IGI Global. https://doi.org/10.4018/978-1-5225-6261-0.ch011

Lemoine, P. A., Hackett, P. T., \& Richardson, M. D. (2016b). Global higher education and VUCA: Volatility, Uncertainty, complexity and ambiguity. In S. Mukerji \& P. Tripathi, The handbook of research on administration, policy and leadership in higher education (pp. 549-568). Hershey, PA: IGI.

Lemoine, P. A., Hackett, T., \& Richardson, M. D. (2016a). Higher education at a crossroads: Accountability, globalism and technology. In W. Nuninger, \& J-M. Chatelet (Eds.), Handbook of research on quality assurance and value management in higher education (pp 27-57). Hershey, PA: IGI. https://doi.org/10.4018/978-1-5225-0024-7.ch002

Lemoine, P. A., Jenkins, W. M., \& Richardson, M. D. (2017). Global higher education: Development and implications. Journal of Education and Development, 1(1), 58-71. https://doi.org/10.20849/jed.v1i1.253

Lewis, S., \& Lingard, B. (2015). The multiple effects of international large-scale assessment on education policy and research. Discourse: Studies in the Cultural Politics of Education, 36(5), 621-637. https://doi.org/10.1080/01596306.2015.1039765

Li, M., \& Zhao, Y. (Eds.) (2015). Exploring learning \& teaching in higher education. New York, NY: Springer. https://doi.org/10.1007/978-3-642-55352-3

Li, Z., \& Lowe, J. (2016). Mobile student to mobile worker: The role of universities in the 'war for talent'. British Journal of Sociology of Education, 37(1), 11-29. https://doi.org/10.1080/01425692.2015.1095636

Lodge, J. M., \& Bonsanquet, A. (2014). Evaluating quality learning in higher education: Re-examining the evidence. Quality in Higher Education, 20(1), 3-23. https://doi.org/10.1080/13538322.2013.849787

Lovett, C. M. (2013). The global contexts of higher education. Change: The Magazine of Higher Learning, 45(1), 73-78. https://doi.org/10.1080/00091383.2013.749169

Machin, S., \& Murphy, R. (2017). Paying out and crowding out? The globalization of higher education. Journal of Economic Geography, 17(5), 1075-1110. https://doi.org/10.1093/jeg/lbx006

Malee-Bassett, R. (2015). Equity remains a most-important challenge facing global higher education. International Higher Education, (80), 5-6. https://doi.org/10.6017/ihe.2015.80.6131

Marginson, S. (2006). Dynamics of national and global competition in higher education. Higher Education, 52(1), 1-39. https://doi.org/10.1007/s10734-004-7649-x 
Marshall, S. (2010). Change, technology and higher education: Are universities capable of organizational change? Research in Learning Technology, 18(3), 179-192. https://doi.org/10.1080/09687769.2010.529107

McClure, K. R. (2016). Building the innovative and entrepreneurial university: An institutional case study of administrative academic capitalism. The Journal of Higher Education, 87(4), 516-543. https://doi.org/10.1353/jhe.2016.0023

McCowan, T., \& Schendel, R. (2015). The impact of higher education on development. In S. McGrath, \& Q. Gu (Eds.), Routledge handbook of international education and development. London: Routledge.

Mense, E. G., Fulwiler, J. H., Richardson, M. D. \& Lane, K. E. (2011). Standardization, hybridization or individualization: Marketing IT to a diverse clientele. In U. Demiray, \& S. Sever (Eds.), Marketing online educational programs: Frameworks for promotion and communication (pp. 291-299). Hershey, PA: IGI. https://doi.org/10.4018/978-1-60960-074-7.ch019

Miller, B. (2010). Skills for sale: What is being commodified in higher education? Journal of Further and Higher Education, 34(2), 199-206. https://doi.org/10.1080/03098771003695460

Mishra, R. (2013). Globalisation and higher education: Threat or opportunity? International Journal of Humanities \& Social Sciences, 1(1), 39-47.

Mohsin, A., \& Zaman, K. (2014). Internationalization of universities: Emerging trends, challenges and opportunities. Journal of Economic Info, 3(1).

Mok, K. H. (2015). Higher education transformations for global competitiveness: Policy responses, social consequences and impact on the academic profession in Asia. Higher Education Policy, 28(1), 1-15. https://doi.org/10.1057/hep.2014.27

Molesworth, M., Scullion, R., \& Nixon, E. (Eds.) (2011). The marketisation of higher education and the student as a consumer. New York, NY: Routledge.

Monteiro, S., \& Sharma, R. (2014). Global interdependence and cultural hybridization: The stimulus for social change. Global Studies Journal, 6(3), 25-32. https://doi.org/10.18848/1835-4432/CGP/v06i03/40898

Moreira, D. P. (2016). From on-campus to online: A trajectory of innovation, internationalization and inclusion. The International Review of Research in Open and Distributed Learning, 17(5). https://doi.org/10.19173/irrodl.v17i5.2384

Morley, L., Marginson, S., \& Blackmore, J. (2014). Education and neoliberal globalization. British Journal of Sociology of Education, 35(3), 457-468. https://doi.org/10.1080/01425692.2014.893072

Nicotra, A. \& Patel, F. (2016). Contesting the political economy of higher education: Educating the good citizen. Journal of International and Global Studies, 7(2), 22-39.

Ornstein, A., \& Eng, N. (2015). 21st Century excellence in education: Introduction. Society, 52(2), 121. https://doi.org/10.1007/s12115-015-9871-9

Peercy, C., \& Svenson, N. (2016). The role of higher education in equitable human development. International Review of Education, 62(2), 139-160. https://doi.org/10.1007/s11159-016-9549-6

Peters, M. A. (2010). Three forms of the knowledge economy: Learning, creativity and openness. British Journal of Educational Studies, 58(1), 67-88. https://doi.org/10.1080/00071000903516452

Pinheiro, R., \& Stensaker, B. (2014). Designing the entrepreneurial university: The interpretation of a global idea. Public Organization Review, 14(4), 497-516. https://doi.org/10.1007/s11115-013-0241-z

Proenza, L. M. (2010). Relevance, connectivity, and productivity: Three paths to innovation in higher education. Innovations, 5(2), 3-11. https://doi.org/10.1162/inov_a_00007

Pucciarelli, F., \& Kaplan, A. (2016). Competition and strategy in higher education: Managing complexity and uncertainty. Business Horizons, 59(3), 311-320. https://doi.org/10.1016/j.bushor.2016.01.003

Qureshi, R., \& Nair, S. (2015). The role of higher education in emerging knowledge society. Global Journal on Humanities and Social Sciences, 1(1), 543-548.

Richardson, M. D., Jenkins, W. M., \& Lemoine, P. A. (2017). Planning for innovation and disruption in a global environment. Educational Planning, 23(3), 11-24.

Saarinen, T., \& Valimaa, J. (2012). Change as an intellectual device and as an object of research. In S. Stensaker, J. Valimaa, \& Sarrico (Eds.), Managing reform in universities (pp. 41-60). London: Palgrave Macmillan. 
Samier, E. A. (2015). The globalization of higher education as a societal and cultural security problem. Policy Futures in Education, 13(5), 683-702. https://doi.org/10.1177/1478210315579558

Seeber, M., Cattaneo, M., Huisman, J., \& Paleari, S. (2016). Why do higher education institutions internationalize? An investigation of the multilevel determinants of internationalization rationales. Higher Education, 72(5), 685-702. https://doi.org/10.1007/s10734-015-9971-x

Shaker, G. G., \& Plater, W. M. (2016). The global public good: Students, higher education, and communities of good. Higher Learning Research Communications, 6(2), 1-9. https://doi.org/10.18870/hlrc.v6i2.332

Sharma, N. K. (2014). Globalization and its impact on the third world economy. Crossing the Border: International Journal of Interdisciplinary Studies, 1(1), 21-28. https://doi.org/10.3126/ctbijis.v1i1.10465

Shin, J. C., \& Kehn, B. M. (Eds.) (2013). Institutionalization of world-class universities in global competition. New York, NY: Springer. https://doi.org/10.1007/978-94-007-4975-7

Siddiqui, K. (2014). Higher education in the era of globalization. International Journal of Humanities and Social Science, 3(2), 9-32

Slaughter, S. (2014). Academic capitalism in the age of globalization. Baltimore, MD: JHU Press.

Soares, L. (2012). A 'disruptive' look at competency-based education: How the innovative use of technology will transform the college experience. Washington, DC: Center for American Progress.

Sobe, N. W. (2015). All that is global is not world culture: Accountability systems and educational apparatuses. Globalisation, Societies and Education, 13(1), 135-148. https://doi.org/10.1080/14767724.2014.967501

Spring, J. (2014). Globalization of education: An introduction. New York, NY: Routledge. https://doi.org/10.4324/9781315795843

Stafford, S., \& Taylor, J. (2016). Transnational education as an internationalisation strategy: Meeting the institutional management challenges. Journal of Higher Education Policy and Management, 38(6), 625-636. https://doi.org/10.1080/1360080X.2016.1202811

Stensaker, B., Lee, J.J., Rhoades, G., Ghosh, S., Castiello-Gutiérrez, S., Vance, H., ... O’Toole, L. (2018). Stratified university strategies: The shaping of institutional legitimacy in a global perspective. The Journal of Higher Education, 14, 1-24. https://doi.org/10.1080/00221546.2018.1513306

Stromquist, N. P., \& Monkman, K. (Eds.) (2014). Globalization and education: Integration and contestation across cultures. New York, NY: R\&L Education.

Tadaki, M., \& Tremewan, C. (2013). Reimagining internationalization in higher education: International consortia as a transformative space? Studies in Higher Education, 38(3), 367-387. https://doi.org/10.1080/03075079.2013.773219

Tannock, S. (2013). When the demand for educational equality stops at the border: Wealthy students, international students and the restructuring of higher education in the UK. Journal of Education Policy, 28(4), 449-464. https://doi.org/10.1080/02680939.2013.764577

Tapscott, D., \& Williams, W. D. (2010). Innovating the 21st-Century university: It's time! Educause Review, 45(1), 16-29.

Taylor, B. J., \& Morphew, C. C. (2015). Trends in cost-sharing in the US and potential international implications. Higher Education Policy, 28(2), 129-149. https://doi.org/10.1057/hep.2013.39

Teichler, U. (2017). Internationalisation trends in higher education and the changing role of international student mobility. Journal of International Mobility, 1(5), 177-216. https://doi.org/10.3917/jim.005.0179

Tekleselassie, A. A., Roberts, E. L., \& Richardson, M. D. (2014). Technology as educational speculation: Mechanism for a continually shifting world. In S. S. Shepherd, P. A. Lemoine, W. Ennis, III, M. D. Richardson, \& J. H. Fulwiler (Eds.), Innovative technology for $21^{\text {st }}$ Century education. Dubuque, IA: Kendall/Hunt.

Temple, P. (2011). Universities in the knowledge economy: Higher education organisation and global change. London: Taylor \& Francis.

Torres, C. A. (2015). Global citizenship and global universities. The age of global interdependence and cosmopolitanism. European Journal of Education, 50(3), 262-279. https://doi.org/10.1111/ejed.12129 
Van Nyhuis, A. (2018). Advancing globalization by teaching with technology: Synthesizing global understanding and collaborative online international learning models. American Association of University Administrators, 33(1), 136-143.

Wadhwa, R. (2016). New phase of internationalization of higher education and institutional change. Higher Education for the Future, 3(2), 227-246. https://doi.org/10.1177/2347631116650548

Walker, M. (2015). Higher education and the public good. In S. McGrath, \& Q. Gu (Eds.), Routledge handbook on international education and development. London: Routledge.

Wangenge-Ouma, G. (2014). Diaspora linkages and the challenge strengthening the academic core in African universities. In M. Stiasny \& T. Gore (Eds.), Global education: Knowledge-based economies for 21st century nations (pp. 19-28). London: Emerald.

Weller, M., \& Anderson, T. (2013). Digital resilience in higher education. European Journal of Open, Distance and e-Learning, 16(1), 41-65.

Woodard, H. C., Shepherd, S. S., Crain-Dorough, M., \& Richardson, M. D. (2011). The globalization of higher education: Through the lens of technology and accountability. I-manager's Journal of Educational Technology, 8(2), 16-24. https://doi.org/10.26634/jet.8.2.1629

Yeoh, B. S., Foong, M., \& Ho, K. (2014). International students and the politics of language among 'globalising universities' in Asia. Knowledge Cultures, 2(4), 64-89.

Youngs, G. (Ed.) (2013). The digital world: Connectivity, creativity and rights. New York, NY: Routledge. https://doi.org/10.4324/9780203767061

Zajda, J. (2015). Globalisation and its impact on education and policy. In J. Zaida (Ed.), Second international handbook on globalisation, education and policy research (pp. 105-125). Dordrecht, Netherlands: Springer. https://doi.org/10.1007/978-94-017-9493-0_7

Zhao, Y. (2012). World class learners: Educating creative and entrepreneurial students. Thousand Oaks, CA: Corwin Press.

Zhao, Y. (2015). A world at risk: An imperative for a paradigm shift to cultivate 21 st Century learners. Society, 52(2), 129-135. https://doi.org/10.1007/s12115-015-9872-8

Zhu, C. (2015). Organisational culture and technology-enhanced innovation in higher education. Technology, Pedagogy and Education, 24(1), 65-79. https://doi.org/10.1080/1475939X.2013.822414 